\title{
Role of cellular compartmentalization in the trophic transfer of mercury species in a freshwater plant-crustacean food chain
}

Rebecca Beauvais-Flück ${ }^{\mathrm{a}}$, Arnaud Chaumot ${ }^{\mathrm{b}}$, Frédéric Gimbert ${ }^{\mathrm{c}}$, Hervé Quéau ${ }^{\mathrm{b}}$, Olivier Geffard $^{\mathrm{b}}$, Vera I. Slaveykova ${ }^{\mathrm{a}}$, Claudia Cosio ${ }^{\mathrm{a} *}$

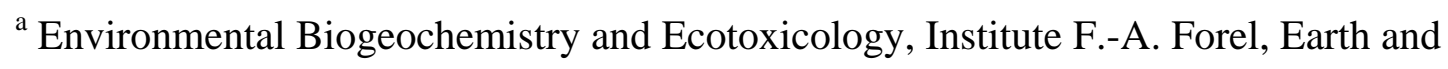
Environmental Sciences, Faculty of Sciences, University of Geneva, 66 bd Carl-Vogt, CH1205 Geneva, Switzerland

${ }^{\mathrm{b}}$ Irstea, UR MALY Milieux aquatiques, écologie et pollutions, centre de Lyon-Villeurbanne, F-69616 Villeurbanne, France.

${ }^{\mathrm{c}}$ Department of Chrono-Environment, University of Bourgogne Franche-Comté, UMR UFC/CNRS 6249 USC INRA, 16 route de Gray, F-25030 Besançon Cedex, France

*Corresponding author: Claudia.Cosio@unige.ch, Phone: +41 2237903 10, Fax: +41 22379 0329 .

Rebecca.Flueck@unige.ch arnaud.chaumot@irstea.fr frederic.gimbert@univ-fcomte.fr herve.queau@irstea.fr olivier.geffard@irstea.fr Vera.Slaveykova@unige.ch 


\begin{abstract}
Mercury $(\mathrm{Hg})$ represents an important risk for human health through the food webs contamination. Macrophytes bioaccumulate $\mathrm{Hg}$ and play a role in $\mathrm{Hg}$ transfer to food webs in shallow aquatic ecosystems. Nevertheless, the compartmentalization of $\mathrm{Hg}$ within macrophytes, notably major accumulation in the cell wall and its impact on trophic transfer to primary consumers are overlooked.

The present work focusses on the trophic transfer of inorganic $\mathrm{Hg}(\mathrm{IHg})$ and monomethyl- $\mathrm{Hg}$ (MMHg) from the intracellular and cell wall compartments of the macrophyte Elodea nuttallii - considered a good candidate for phytoremediation - to the crustacean Gammarus fossarum. The results demonstrated that $\mathrm{Hg}$ accumulated in both compartments was trophically bioavailable to gammarids. Besides IHg from both compartments were similarly transferred to G. fossarum, while for MMHg, uptake rates were 2.5 -fold higher in G. fossarum fed with the cell wall vs the intracellular compartment. During the depuration phase, $\mathrm{Hg}$ concentrations in G. fossarum varied insignificantly suggesting that both IHg and MMHg were strongly bound to biological ligands in the crustacean. Our data imply that cell walls have to be considered as an important source of $\mathrm{Hg}$ to consumers in freshwater food webs when developing procedures for enhancing aquatic environment protection during phytoremediation programs.
\end{abstract}

Keywords: cell wall, depuration, intracellular, toxicokinetics, bioaccumulation 


\section{Introduction}

Mercury $(\mathrm{Hg})$ is a pollutant known to bioaccumulate in organisms and that can cause serious threat to the ecosystems and eventually human health [1]. In the aquatic environment, $\mathrm{Hg}$ accumulation and effects have been widely studied in biota, notably in fish: the organic form of $\mathrm{Hg}$, monomethyl- $\mathrm{Hg}(\mathrm{MMHg})$ and inorganic $\mathrm{Hg}(\mathrm{IHg})$ are both toxic, but $\mathrm{MMHg}$ has been shown to biomagnify through the food chain while $\mathrm{IHg}$ does not [2]. Dietary transfer of $\mathrm{Hg}$ is considered as being determinant for its effects on higher trophic animals [3]. Indeed, small increase of $\mathrm{Hg}$ levels in food can depress reproductive capabilities in herbivores, while direct exposure to similar concentrations is less detrimental [4]. Primary producers at the base of the food chain are thus central for the entry of $\mathrm{Hg}$ and its subsequent impact on higher trophic levels. Nonetheless, the precise factors controlling the transfer of $\mathrm{Hg}$ from primary producers to heterotroph consumers as well as the mechanisms and characteristics of these transfers remain poorly understood [5].

Macrophytes are key organisms of shallow aquatic environment in which $\mathrm{MMHg}$ is produced [6]. The ability of aquatic macrophytes to accumulate and tolerate high levels of IHg and MMHg make them useful for phytoremediation purposes, biomonitoring or for ecotoxicology testing [6-8]. On the other hand, macrophytes have been identified as having a role in $\mathrm{Hg}$ transfer to food webs in shallow aquatic ecosystems [2,9]. Limited literature shows that accumulation of $\mathrm{Hg}$ in plants and other primary producers varies with species: the flowering plant Elodea nuttallii accumulated consistently higher $\mathrm{Hg}$ concentrations than another flowering plant Ceratophyllum demersum and seston sampled in several stations along a contaminated river in Romania [6, 10]. It was proposed that cell wall properties might explain in part differences in bioaccumulation in unicellular algae [11]. It is indeed well-known that plants use subcellular compartmentalization to limit the amount of toxic metal bound to sensitive targets $[7,12,13]$. Metals, including $\mathrm{Hg}$, have been shown to be predominantly accumulated in cell walls in macrophytic angiosperms exposed to environmental concentrations in the microcosm and in the field [7, 14]. Besides, earlier studies on other primary producers, in this case diatoms, suggested that intracellularly accumulated $\mathrm{MMHg}$ was primarily transferred to copepods, while $\mathrm{Hg}$ accumulated in membranes and silicate frustules was not assimilated [15, 16], but this data awaits further confirmation in other primary producers to be generalized. In sum, the fate of $\mathrm{Hg}$ in cell wall $v s$ internalized $\mathrm{Hg}$, notably their respective transfer from macrophytes to herbivores and hence role in $\mathrm{Hg}$ transfer to food webs is overlooked. 
The objective of this study was therefore to understand the role of $\mathrm{IHg}$ and $\mathrm{MMHg}$ compartmentalization in plants on the trophic transfer to invertebrates in an experimental freshwater flowering plant-invertebrate food chain. Recently we identified in an $\mathrm{Hg}$ contaminated river in Romania, a macrophyte E. nuttallii, that showed high bioaccumulation of $\mathrm{Hg}$, notably in its cell walls, and was at the base of the littoral-benthic food chain, representing hence a good model to study $\mathrm{Hg}$ transfer [2, 7, 8, 10, 17]. More in detail, we aimed to address the following questions: (i) Are IHg and MMHg accumulated in E. nuttallii transferred to Gammarus fossarum chosen as a surrogate for aquatic herbivores and decomposers? and (ii) How the compartmentation of $\mathrm{Hg}$ in the plant may influence its transfer to this primary consumer? This fundamental knowledge will help to further determine the susceptibility of $\mathrm{Hg}$ to enter macrophyte-based food web as well as will allow designing improved strategies for mitigation of $\mathrm{Hg}$ bioaccumulation and entry in food webs during phytoremediation programs.

\section{Experimental}

\subsection{Labware cleaning}

All material was soaked in (i) detergent 1 week, (ii) twice in $\mathrm{HNO}_{3} 10 \%$ (v/v; pro analysis Sigma, Buchs, Switzerland) 1 week, (iii) in $\mathrm{HCl} \mathrm{10 \%} \mathrm{(v/v;} \mathrm{pro} \mathrm{analysis} \mathrm{Sigma,} \mathrm{Buchs,}$ Switzerland) 1 week, thoroughly rinsed with MilliQ water (MilliQ Direct system, Merck Millipore, Darmstadt, Germany) after each washing step and dried under a laminar flow hood.

\subsection{Exposure of Elodea nuttallii}

Ten cm-long shoots of E. nuttallii without roots were collected in the Etournels pound (France; $46^{\circ} 07^{\prime} 58^{\prime \prime} \mathrm{N}$ and $05^{\circ} 56^{\prime} 46^{\prime \prime} \mathrm{E}$ ), brought to the laboratory and acclimated $48 \mathrm{~h}$ in laboratory conditions: filtered water $(1.2 \mu \mathrm{m})$ sampled in Lake Geneva, with controlled conditions at $20^{\circ} \mathrm{C}, 16 / 8 \mathrm{~h}$ light/dark photoperiod, 1000 lux. Forty-eight shoots were exposed (or not: control) in 2.5 $\mathrm{L}$ tanks for $2 \mathrm{~h}$ to $0.2,4,20 \mu \mathrm{g} \cdot \mathrm{L}^{-1} \mathrm{MMHg}\left(\mathrm{CH}_{3} \mathrm{HgCl}\right.$; Alfa Aesar, Ward Hill, MA, USA) or IHg ( $\mathrm{HgCl}_{2}$; Alfa Aesar, Ward Hill, MA, USA). The exposure concentrations in water were chosen based on previous studies to result in concentrations in shoots after $2 \mathrm{~h}$-long exposure covering the amount of $\mathrm{Hg}$ accumulated in macrophytes in the uncontaminated to contaminated environments $[2,6]$.

To assess the impact on compartmentalization in plants on subsequent $\mathrm{Hg}$ transfer, shoots were processed by two different procedures applied to retain $\mathrm{Hg}$ accumulated either 
intracellularly or in cell walls while conserving the shoot morphology. To prepare shoots containing only intracellular $\mathrm{Hg}$, shoots were rinsed for $10 \mathrm{~min}$ with ethylene-diamine-tetra-acetic acid (EDTA; $1 \mathrm{mM}$; AppliChem, Darmstadt, Deutschland) and cysteine (1 mM; Sigma-Aldrich, Buchs, Switzerland). This extraction procedure is based on the competition for $\mathrm{Hg}$ binding between ligands on biota and molecules with high affinity to $\mathrm{Hg}$ and was previously shown to be the highly efficient for removal of IHg and $\mathrm{MMHg}$ in the cell wall [7]. To prepare shoots containing only $\mathrm{Hg}$ bound in the cell wall, shoots were soaked 3d in methanol-chloroform (v/v 2:1; Sigma, Buchs, Switzerland) to remove membrane phospholipids and hence dissolve membranes and purify intact cell walls as described before [7]. Shoots were in addition rinsed for $5 \mathrm{~min}$ in milliQ water prior and after both treatments.

\subsection{Exposure of Gammarus fossarum}

Gammarus fossarum were collected from the Bourbre River (France) from the same population as in [18, 19]. Organism sampling was carried three weeks before exposure, allowing acclimatization in laboratory conditions (drilled groundwater, water temperature $12^{\circ} \mathrm{C}$, constant oxygenation, conductivity $\sim 500 \mu \mathrm{S} \cdot \mathrm{cm}^{-1}, 16 / 8 \mathrm{~h}$ light/dark photoperiod, ad libitum feeding with alder leaves. Alder leaves were analysed for their $\mathrm{Hg}(0.04 \pm 0.02$ $\mu \mathrm{g} \cdot \mathrm{total}^{\mathrm{Hg} \cdot \mathrm{g}^{-1}}$ d.w. $)$ and $\mathrm{MMHg} \quad\left(0.95 \pm 0.02 \quad \mathrm{ng} \cdot \mathrm{MMHg}^{-\mathrm{g}^{-1}}\right.$ d.w. $)$ background concentrations.

As operated in previous study [19], we took care in the selection of exposed organisms to limit any confounding influence of biotic factors on the level of $\mathrm{Hg}$ in tissues. In that way, nine individual males homogeneous in size $(1 \mathrm{~cm}$-long), were exposed in triplicates in 500 $\mathrm{mL}$ polypropylene beakers with oxygenated water maintained at a temperature of $14^{\circ} \mathrm{C}$ and renewed continuously ( 8 renewals $\cdot \mathrm{d}^{-1}$ ) to limit direct $\mathrm{Hg}$ exposure by the water (e.g. aqueous released $\mathrm{Hg}$ from plants). Ten shoots were added to the beaker at the beginning of the exposure. Two exposure scenarios were conducted: Experiment 1 (bioaccumulation) consisted in a 7 day-long exposure of gammarids to plants pre-exposed to the different concentrations of $\mathrm{IHg}$ and $\mathrm{MMHg}$. This experiment allowed to assess the importance of $\mathrm{Hg}$ transfer from macrophytes to gammarids and subsequently to choose an optimal concentration for experiment 2. Experiment 2 (toxicokinetics) consisted in 2, 4, 7 day-long exposure of gammarids to plants exposed to the intermediate concentrations of $\mathrm{IHg}$ and $\mathrm{MMHg}$ and 7 days of further depuration to assess dynamics of transfer according to $\mathrm{Hg}$ form and shoot's compartment. For depuration, individuals were transferred to a clean beaker and fed 7 
supplemental days with alder leaves. At the end of the experiments, gammarids were collected, carefully dried and immediately snap frozen in liquid nitrogen.

\subsection{Determination of mercury in water, macrophytes and gammarids}

Total $\mathrm{Hg}(\mathrm{THg}=\mathrm{MMHg}+\mathrm{IHg})$ concentration in freeze-dried organisms was measured using an AMA-254 (Altec s.r.l., Dvůr Králové nad Labem, Czech Republic). The detection limit was $0.003 \mu \mathrm{g} \cdot \mathrm{THg} \cdot \mathrm{g}^{-1}$. The accuracy of the measurements was checked by analysing the certified reference material (CRM) MESS-3. The measurement error was usually about 3\% and always below $6 \%$.

THg concentration in water was measured with a MERX (Brooks Rand instruments, Seattle, WA, USA) following $\mathrm{THg}$ procedure [20]. The detection limit was $0.03 \mathrm{ng} \cdot \mathrm{THg} \cdot \mathrm{L}^{-1}$. The accuracy of $\mathrm{THg}$ measurements was tested by analyzing the CRM ORMS-5. The measurement error was usually about $2 \%$ and always below $5 \%$.

$\mathrm{MMHg}$ in freeze-dried and ground gammarids was extracted by $\mathrm{HNO}_{3}$ (Suprapur®, Merck Darmstadt, Germany) leaching, $12 \mathrm{~h}$ at $60^{\circ} \mathrm{C}$. Organisms and water samples were then analyzed with a MERX (Brooks Rand instruments, Seattle, WA, USA) following MMHg procedure $[21,22]$. The detection limit was $0.002 \mathrm{ng} \cdot \mathrm{MMHg} \cdot \mathrm{L}^{-1}$. The accuracy of $\mathrm{MMHg}$ measurements was tested by analyzing the CRM TORT-2. The measurement error was usually about $15 \%$ and always below $25 \%$.

Concentrations in water were measured at the beginning of the exposure of plants (Table A1). For IHg exposure scenarios, $\mathrm{MMHg}$ was below the detection limit, and hence $\mathrm{THg}=\mathrm{IHg}$. For $\mathrm{MMHg}$, we considered that $\mathrm{THg}=\mathrm{MMHg}$ in water as no demethylation is expected in water in these conditions as shown previously [7].

\subsection{Modelling of $\mathrm{Hg}$ accumulation by Gammarus fossarum}

The variation of concentrations in gammarids with time can be modelled by a toxicokinetic one-compartment equation, allowing uptake and excretion rates to be estimated [23]. Our data highlighted the absence of significant excretion over the 7-day-long exposure period considered (data not shown), hence a simplified linear model to describe accumulation kinetics over time was used (Eq.(1)):

$$
C_{m}(t)=C_{m}(0)+a \times t
$$


where $C_{m}(t)$ is the $\mathrm{Hg}$ concentrations in gammarids $\left(\mu \mathrm{g} \cdot \mathrm{g}^{-1} \mathrm{dw}\right)$ at time $\mathrm{t}$ (days); $C_{m(0)}$ is the constitutive $\mathrm{Hg}$ concentration measured in gammarids at the beginning of the experiment and $a$ is the uptake rate $\left(\mu \mathrm{g} \cdot \mathrm{Hg} \cdot \mathrm{g}_{\text {gammarid }}{ }^{-1} \cdot \mathrm{d}^{-1}\right)$. The uptake rate $a$ depends on both the concentration of $\mathrm{Hg}$ species in E. nuttallii compartments $\left(C_{\text {plant }}\right.$, in $\left.\mu \mathrm{g} \cdot \mathrm{Hg} \cdot \mathrm{g}_{\mathrm{plant}}{ }^{-1}\right)$ and an uptake rate constant $\left(k_{u}\right.$, in $\left.\mathrm{g}_{\text {plant }} \cdot \mathrm{g}_{\text {gammarid }}{ }^{-1} \cdot \mathrm{d}^{-1}\right)$ representing the exposure of gammarids to contaminated plants, linked to assimilation efficiency (AE; conversion of resource biomass into consumer biomass) and ingestion rate (IR; biomass of resource ingested per day). This uptake rate constant can be derived according to the equation (Eq.(2)):

$$
k_{u}=\frac{a}{C_{\text {plant }}}
$$

\subsection{Statistical analysis}

We performed an analysis of variance (ANOVA, $p<0.05$ ) with a post-hoc Tukey's HSD test $(p<0.05)$ for pairwise comparisons of bioaccumulation data. The uptake rates were estimated by fitting the toxicokinetic model with a linear model function (lm) [24]. When residuals were skewed, variance functions (power and exponential) were applied and the best model was selected according to Akaike's Information Criterion (AIC, pgirmess R package). Differences in parameter estimates between exposure modalities and subcellular fractions were checked using a generalized likelihood ratio test (GLRT). All statistics were performed with the free statistical software package $\mathrm{R}$ version 3.1.3 [25].

\section{Results and discussion}

\subsection{Hg accumulation and compartmentalization in E. nuttallii}

Accumulation of $\mathrm{THg}$ and $\mathrm{MMHg}$ in both the intracellular and the cell wall compartment of E. nuttallii was first determined (Table 1). The obtained $\mathrm{THg}$ and $\mathrm{MMHg}$ contents in shoots covered the whole range of concentrations found in E. nuttallii collected in clean $(0.05$ $\mu \mathrm{g} \cdot \mathrm{THg} \cdot \mathrm{g}^{-1}$ ) and in contaminated sites, that reached for example $2 \mu \mathrm{g} \cdot \mathrm{THg} \mathrm{g}{ }^{-1}$ in a $\mathrm{Hg}_{-}$ contaminated reservoir in Romania $[2,10]$. As E. nuttallii is highly tolerant to $\mathrm{Hg}$, toxicity of $\mathrm{Hg}$ to this plant, here as well as in natural water, is very unlikely $[7,10]$.

Mercury bioaccumulation in E. nuttallii after $2 \mathrm{~h}$ at the lowest concentrations of exposure $(0.2$ $\mu \mathrm{g} \cdot \mathrm{L}^{-1}$ ) was insignificant compared with non-exposed shoots (Control) for both $\mathrm{THg}$ and MMHg and intracellular compartments (Table 1). In terms of concentrations, bioaccumulation of $\mathrm{THg}$ is higher for the cell wall than the intracellular compartment, in particular for $\mathrm{MMHg}$ 
$20 \mu \mathrm{g} \cdot \mathrm{L}^{-1}$ exposure treatment. These findings are in line with previous studies showing $\sim 60 \%$ of THg being bound in cell walls in E. nuttallii after 4 days of exposure at $76 \mathrm{ng} \cdot \mathrm{L}^{-1} \mathrm{IHg}$ and $23 \mathrm{ng} \cdot \mathrm{L}^{-1} \mathrm{MMHg}$ in water [7], hence supporting an important role of the cell wall in $\mathrm{Hg}$ binding. Indeed, cell walls of primary producers are very important sink for $\mathrm{Hg}$ [7, 14]. Moreover, differences in $\mathrm{Hg}$ accumulation in algae were attributed to their cell wall properties and proposed to control intracellular concentrations and hence the transfer in consumers [11]. On the other hand, comparable bioaccumulation of $\mathrm{MMHg}$ than IHg in both the intracellular and the cell wall compartments after $2 \mathrm{~h}$ (Table 1) suggests similar accumulation capacity for both species at the studied concentrations. This could be attributed to the short-term exposure. For comparison, in E. nuttallii steady-state internal concentration of 0.40 and $1.09 \mu \mathrm{g} \cdot \mathrm{THg} \cdot \mathrm{g}^{-1}$ was reached after more than $8 \mathrm{~h}$ for $23 \mathrm{ng} \cdot \mathrm{L}^{-1} \mathrm{MMHg}$ and $48 \mathrm{~h}$ for $76 \mathrm{ng} \cdot \mathrm{L}^{-1} \mathrm{IHg}$, respectively [7]. Nevertheless, another study with Chlamydomonas reinhardtii exposed $48 \mathrm{~h}$ to $\mathrm{IHg}$ and $\mathrm{MMHg}$ under low environmentally relevant concentrations in the laboratory in absence of organic matter, also reported similar intracellular concentrations for $\mathrm{IHg}$ and $\mathrm{MMHg}$, supporting similar accumulation capacities for $\mathrm{IHg}$ and $\mathrm{MMHg}$ in this green alga, a close relative of flowering plants, in line with their similar lipid solubility $[16,26]$. On the opposite, a 2- to 4-fold higher uptake of MMHg than $\mathrm{IHg}$ is regularly reported in natural food webs [2, 6 , 15, 16]. These discrepancies mostly highlight that mechanisms resulting in biomagnification of $\mathrm{MMHg}$, but no biomagnification of $\mathrm{IHg}$ in food webs are not understood in detail yet.

Concerning $\mathrm{MMHg}$, in our conditions background $\mathrm{THg}$ concentration measured in unexposed shoots (Control) consisted of $\sim 80 \%$ and $100 \% \mathrm{MMHg}$ in the intracellular and the cell wall compartment, respectively (Table 1). The ratio of $\mathrm{MMHg}$ to the $\mathrm{THg}$ decreased for shoots exposed to $\mathrm{IHg}$ and increased both in intracellular and cell wall compartments exposed to MMHg compared to control conditions (Table 1). Here, no demethylation for $\mathrm{MMHg}$ exposure (i.e. $\mathrm{MMHg}=\mathrm{THg}$ ), and no methylation is expected for $\mathrm{IHg}$ exposure in water in this short-term exposure conditions as observed in previous experiments [7]. Besides, our data support the absence of substantial demethylation by shoots during bioaccumulation as indicated by $\geq 100 \% \mathrm{MMHg} / \mathrm{THg}$ proportion in the cell wall and intracellular compartments, except in the intracellular compartment for $\mathrm{MMHg} 0.2 \mu \mathrm{g} \cdot \mathrm{L}^{-1}$ resulting in $0.57 \pm 0.29$ $\mathrm{MMHg} / \mathrm{THg}$ ratio. At this latter concentration, a demethylation was observed in shoots of $E$. nuttallii. Similarly, in phytoplankton and zooplankton a minor demethylation and negligible methylation have been reported after $48 \mathrm{~h}$ - and 2 week- exposure, respectively, to IHg and MMHg [26, 27]. 


\subsection{Hg accumulation in Gammarus fossarum}

\subsubsection{Role of Hg compartmentalization in E. nuttallii}

Experiment 1 consisted in feeding gammarids with the intracellular or the cell wall compartments of E. nuttallii pre-exposed to various $\mathrm{IHg}$ and $\mathrm{MMHg}$ concentrations and measuring $\mathrm{Hg}$ bioaccumulation in gammarids after 7 days. To exclude confounding or indirect effects, the mortality was monitored daily and dead animals were removed. Cannibalism was thus avoided, which ensured that gammarids were only exposed to $\mathrm{Hg}$ through plants consumption. The mortality of gammarids during exposure was around $15 \%$ in all conditions. This weak mortality was not correlated with $\mathrm{Hg}$ treatments (concentration or $\mathrm{IHg} / \mathrm{MMHg}$ ), nor with the plant treatment (intracellular/cell wall) highlighting the absence of toxicity of our experimental conditions.

Concentrations measured in gammarids fed with control intracellular or cell wall compartments were in the range previously found for amphipods collected in the field ranging from 0.05 to $0.2 \mu \mathrm{g} \cdot \mathrm{THg} \cdot \mathrm{g}^{-1}[19,28,29]$. $\mathrm{THg}$ and $\mathrm{MMHg}$ concentrations both linearly increased in gammarids with the concentrations found in E. nuttallii compartments (Figures 1 and 2), suggesting that assimilation efficiency (AE) and ingestion rate (IR) were unaffected by the range of $\mathrm{Hg}$ concentration tested here. On the other hand, the cell wall compartment resulted in higher slopes and concentrations in gammarids than the intracellular compartments (Figure 1A), suggesting that THg in the cell wall was more transferable to gammarids than THg in the intracellular compartment. Nevertheless, it can be questioned whether AE and IR were similar amongst the gammarids fed with the intracellular compartment and the cell wall compartment, as we were unsuccessful in estimating food amount ingested by gammarids. Previous studies concerning $\mathrm{IHg}$ and $\mathrm{MMHg}$ showed that $\mathrm{AE}$ were different for killifish (Fundulus heteroclitus) fed with different food sources, e.g. amphipods or worms [5]. Besides, here when considering $\mathrm{THg}$, the higher slope of the linear increase of $\mathrm{THg}$ in $G$. fossarum with $\mathrm{THg}$ in E. nuttallii suggested that $\mathrm{MMHg}$ was more transferable than $\mathrm{IHg}$ (Figure 1A). In the same line, the ratio of $\mathrm{MMHg}$ to $\mathrm{THg}$ increased with increasing $\mathrm{MMHg}$ exposure from $0.14 \pm 0.05$ to $0.78 \pm 0.05$ and $0.16 \pm 0.02$ to $0.47 \pm 0.09$ for $\mathrm{MMHg} 0.2$ and $20 \mu \mathrm{g} \cdot \mathrm{L}^{-1}$ in intracellular and cell wall compartments, respectively. Nevertheless, $\mathrm{MMHg}$ to $\mathrm{THg}$ ratios in gammarids are globally lower than $\mathrm{MMHg} / \mathrm{THg}$ ratio in shoots, suggesting that a significant part of MMHg is demethylated during feeding in our conditions, while no methylation is observed in the IHg exposure conditions. The above findings are consistent with the observation that most of the initial MMHg being demethylated in seston (70\%) and 
zooplankton (13\%) in their experimental food chain involving algae and zooplankton [27]. Moreover, when looking at $\mathrm{IHg}$ and $\mathrm{MMHg}$ concentration in gammarids after feeding with MMHg-exposed-shoots $v s$ concentration in shoots, $\mathrm{IHg}$ resulted in a higher slope than $\mathrm{MMHg}$ (Figure 1B), which is opposite to expected results based on MMHg biomagnifications in natural food chains $[2,6]$. Indeed, $\mathrm{AE}$ of $\mathrm{MMHg}$ has been repeatedly shown to be higher than $\mathrm{AE}$ of $\mathrm{IHg}[5,30-33]$. Unfortunately, most studies only measured $\mathrm{THg}$, hence suffering from a lack of reliable information concerning $\mathrm{AE}$ for $\mathrm{MMHg}$ and $\mathrm{IHg}$ and not allowing comparison with our data. However, here we can question whether AE was comparable for $\mathrm{IHg}$ and $\mathrm{MMHg}$ as both $\mathrm{Hg}$ form shows different binding sites at the subcellular level in shoots and might subsequently show different trophic availability [10, 33]. It was proposed that in plants, $\mathrm{Hg}$ could be retained in cell walls by means of extracellular carbohydrates, such as pectic sites or hystidyl groups forming very stable complexes, or be associated with thiols or cysteines of cell wall proteins like extensin, which contains a Cys-rich domain [34]. Similarly, the intracellular $\mathrm{Hg}$ is expected to be bound via a sulfhydryl cysteine group of biothiols such as glutathione or phytochelatins and exported to vacuoles [35, 36]. In the intracellular fraction of different fish preys, $\mathrm{MMHg}$ was proposed to be bound in higher proportion to heat-stable-protein than $\mathrm{IHg}$ and thus more available for trophic transfer to fish [33]. Here, it is not known if $\mathrm{IHg}$ and $\mathrm{MMHg}$ are really bound in a similar manner in shoots of E. nuttallii and if their availability for the trophic transfer is similar. However, linear correlation between $\mathrm{Hg}$ in gammarids and shoots supported that $\mathrm{Hg}$ in the cell wall and in the intracellular compartment in the form of $\mathrm{MMHg}$ and $\mathrm{IHg}$ were all trophically available, at least in part, to gammarids.

\subsubsection{Kinetics of Hg transfer from shoots compartments to G. fossarum}

To gain further insights on $\mathrm{Hg}$ transfer dynamics in G. fossarum, we determined the $\mathrm{THg}$, $\mathrm{IHg}$ and $\mathrm{MMHg}$ toxicokinetics in organisms exposed to moderately contaminated E. nuttallii, i.e.

$\mathrm{IHg} 4 \mu \mathrm{g} \cdot \mathrm{L}^{-1}$ (Figure 2) and MMHg $4 \mu \mathrm{g} \cdot \mathrm{L}^{-1}$ (Figure 3), resulting in between 0.4 to 0.8 $\mu \mathrm{g} \cdot \mathrm{THg} \cdot \mathrm{g}^{-1}$ in shoots' compartments (Table 1) for 7 days and further 7 days of depuration. Generally, the one-compartment model without taking into consideration the excretion adequately described the $\mathrm{Hg}$ accumulation from E. nuttallii to gammarids as reflected by the coefficients of determination $\left(\mathrm{R}^{2}\right.$; Table 2$)$.

In G. fossarum exposed to $\mathrm{IHg}$ contaminated E. nuttallii, the exposure compartment (intracellular or cell wall) did not influence the accumulation patterns, i.e. no significant bioaccumulation of $\mathrm{MMHg}$ (although it represented 7 to $10 \%$ of the $\mathrm{THg}$ in plants, Table 1), 
and a linear increase of bioaccumulated IHg vs time $\left(0.020\right.$ and $0.023 \mu \mathrm{g} \cdot \mathrm{IHg} \cdot \mathrm{g}_{\text {gammarid }}{ }^{-1} \cdot \mathrm{d}^{-1}$ for intracellular and cell wall compartments, respectively; Table 2). Considering the similar concentration of $\mathrm{THg}$ and $\mathrm{IHg}$ in the two types of diet, we calculated uptake rate constants of 30 and $31 \mathrm{~g}_{\text {plant }} \cdot \mathrm{g}_{\text {gammarid }}{ }^{-1} \cdot \mathrm{d}^{-1}$ (Table 2). Hence, the type of diet did not seem to influence the exposure of gammarids: $\mathrm{IHg}$ appeared to be similarly trophically transferred from the intracellular and the cell wall compartment of E. nuttallii to G. fossarum.

For MMHg exposed organisms, we evidenced important differences in the $\mathrm{Hg}$ availability and transfer according to the exposure compartment with uptake rates $\sim 2.5$-fold higher in $G$. fossarum exposed to the cell wall compartment compared with the intracellular compartment (Table 2). To account for differences in Hg concentrations in the intracellular and cell wall compartments, uptake rate constants $\left(\mathrm{k}_{\mathrm{u}}\right)$ were derived and revealed different values than those calculated for $\mathrm{IHg}$ exposure, i.e. higher for $\mathrm{THg}\left(0.051\right.$ and $\left.0.067 \mathrm{~g}_{\text {plant }} \cdot \mathrm{g}_{\text {gammarid }}{ }^{-1} \cdot \mathrm{d}^{-1}\right)$ and lower for MMHg (0.014 and $0.021 \mathrm{~g}_{\text {plant }} \cdot \mathrm{g}_{\text {gammarid }}{ }^{-1} \cdot \mathrm{d}^{-1}$; Table 2). In addition to confounding effects possibly due to different (i) AE and IR and (ii) subcellular distribution of $\mathrm{IHg}$ and MMHg discussed above, two hypotheses may be further evoked. Firstly, the gammarids fed differently according to the $\mathrm{Hg}$ species in the food. However, this kind of behavioural avoidance is unlikely because of the relatively low concentrations measured in the E. nuttallii compartments (from 0.4 to $0.8 \mu \mathrm{g} \cdot \mathrm{THg} \cdot \mathrm{g}^{-1}$ ). Secondly, the gammarids had access to less MMHg than expected due to demethylation. This second hypothesis is supported by two results: (i) the decrease of $\mathrm{MMHg} / \mathrm{THg}$ ratios with time in G. fossarum tissues (Figure 3) and (ii) the significant and quite elevated uptake rates modelled for $\mathrm{IHg}$ (Table 2) while this $\mathrm{Hg}$ species is absent from E. nuttallii compartments at the beginning of exposure (Table 1). The demethylation was more pronounced for the cell wall than the intracellular compartment, notably for $\mathrm{MMHg} 20 \mu \mathrm{g} \cdot \mathrm{L}^{-1}(p<0.05)$. However, it remains unclear when this demethylation occurred, i.e. in the plant tissues on which the gammarids fed (due to, for instance, plant material decay and microbial biotransformation), or within the gammarids (during digestion, metabolization).

During the 7 day-long depuration phase, and in line with the linear accumulation patterns, $\mathrm{Hg}$ concentrations in G. fossarum did not significantly vary (Figures 2 and 3). Data therefore suggest that in gammarids the accumulated $\mathrm{IHg}$ and $\mathrm{MMHg}$ were strongly bound to biological ligands, e.g. proteins (sulfhydryl groups) or small peptides such as glutathione or Hg-cysteine complexes [35-37]. Recently, it was found that about $90 \%$ of $\mathrm{Hg}$ was accumulated in the cytosolic fraction of Chironomus riparius midge larvae exposed to IHg spiked sediments and partitioned between the sensitive (mostly enzyme) and detoxified (metallothionein-like) 
components [23]. This latter kind of detoxification strategy probably also could explain the absence of excretion in G. fossarum in our exposure condition [38]. Indeed, Experiment 1 (bioaccumulation, Figure 1) showed that internal concentrations may reach much higher levels, without significant toxicity, than those found during Experiment 2 (kinetic; Table 2), when exposed to higher $\mathrm{Hg}$ concentrations. Gammarids were therefore certainly able to progressively sequester all the $\mathrm{IHg}$ and $\mathrm{MMHg}$ entering their tissues during Experiment 2 preventing both the induction of toxicity and the excretion of $\mathrm{Hg}$.

To summarize, G. fossarum fed on E. nuttallii accumulates $\mathrm{IHg}$ and $\mathrm{MMHg}$ from both intracellular and cell wall compartments. In line with the existing literature, when measuring $\mathrm{THg}, \mathrm{MMHg}$-exposed shoots leads to a higher accumulation of $\mathrm{THg}$ than IHg-exposed shoots, but when measuring MMHg, we observed a significant demethylation of MMHg in gammarids compared to plants. However, here in our experimental conditions, we did observe a significant biotransfer of $\mathrm{IHg}$ and $\mathrm{MMHg}$. Moreover, our data evidenced that opposite to the general hypothesis, $\mathrm{Hg}$ bound in the cell wall of flowering plants such as E. nuttallii can be transferred and assimilated by $\mathrm{G}$. fossarum as is $\mathrm{Hg}$ found in the intracellular compartment. The previous finding that mostly intracellular $\mathrm{MMHg}$ was transferable to primary consumers was conducted on diatoms, which cell wall made of silica (hydrated silicon dioxide; frustule) is completely different from pecto-cellulosic cell wall of plants, and copepods [16]. Moreover, opposite to copepods, gammarids used in the present study feed on leaves and thus are able to degrade cell walls of plants. In the same line, it was found that the amphipods Hyallela azteca had higher capacity to assimilate $\mathrm{Hg}$, than copepods feeding on a deteriorated diatom culture [15]. Besides, it was demonstrated that trophic transfer of MMHg from the phytoplankton in the water column was the major uptake route for the estuarine amphipod Leptocheirus plumulosus [39], suggesting that our findings are generalizable to other photosynthetic organisms, notably plants and microalgae.

Although the subcellular metal distribution is determinant for many consumers that are unable to assimilate the insoluble fraction of the cell, the digestive strategies to handle food of the consumer are also important. Hence, feeding behaviour of consumers might be central for the fate of $\mathrm{Hg}$ in food webs. Therefore, species abundance, notably their capacities of bioaccumulation and feeding respectively for primary producers and consumers, may be considered for enhancing aquatic environment protection as they will significantly influence the fate of $\mathrm{Hg}$ in food webs during phytoremediation programs. 


\section{Conclusion}

The plant-animal interface plays a crucial ecological and ecotoxicological role in aquatic ecosystems as a driver of nutrients and contaminants to higher trophic levels. The present study on accumulation of $\mathrm{IHg}$ and $\mathrm{MMHg}$ in the macrophyte E. nuttallii and then dietary transfer to macroinvertebrates demonstrated that $\mathrm{Hg}$ species in both the intracellular and the cell wall compartments are significant sources of $\mathrm{Hg}$ for the macroinvertebrate G. fossarum. As cell wall constituents are recalcitrant by nature, they are expected to remain longer in the environment. Our data hence point out the cell wall as a new important source of $\mathrm{Hg}$ transfer to consumers in local food webs to be considered for enhancing aquatic environment protection during phytoremediation programs. Moreover, our data supports that the different binding sites at the subcellular level in shoots of $\mathrm{MMHg}$ and $\mathrm{IHg}$ might subsequently result in different trophic availability to consumers. Besides, our data suggest that different $\mathrm{AE}$ for $\mathrm{IHg}$ and for MMHg in consumers might explain the biomagnification of MMHg in food webs.

\section{Funding}

This work was supported by the Swiss National Science Foundation projects $\mathrm{n}^{\circ}$ 205321_138254 and 200020_157173.

\section{References}

[1] Boening, D.W., Ecological effects, transport, and fate of mercury: a general review, Chemosphere, 40(2000) 1335-1351.

[2] Bravo, A.G., C. Cosio, D. Amouroux, J. Zopfi, P.-A. Chevalley, J.E. Spangenberg, V.G. Ungureanu, and J. Dominik, Extremely elevated methyl mercury levels in water, sediment and organisms in a Romanian reservoir affected by release of mercury from a chlor-alkali plant, Water Res., 49(2014) 391-405

[3] Lawrence, A.L. and R.P. Mason, Factors controlling the bioaccumulation of mercury and methylmercury by the estuarine amphipod Leptocheirus plumulosus, Environ. Pollut., 111(2001) 217-31.

[4] Fisher, N.S. and S.E. Hook, Toxicology tests with aquatic animals need to consider the trophic transfer of metals, Toxicology, 182(2002) 531-6.

[5] Dutton, J. and N.S. Fisher, Bioaccumulation of As, Cd, Cr, $\mathrm{Hg}(\mathrm{II})$, and $\mathrm{MeHg}$ in killifish (Fundulus heteroclitus) from amphipod and worm prey, Sci. Total. Environ., 409(2011) 3438-3447. 
[6] Cosio, C., R. Fluck, N. Regier, and V.I. Slaveykova, Effects of macrophytes on the fate of mercury in aquatic systems, Environ. Toxicol. Chem., 24(2014) 1225-1237.

[7] Larras, F., N. Regier, S. Planchon, J. Poté, J. Renaut, and C. Cosio, Physiological and proteomic changes suggest an important role of cell walls in the high tolerance to metals of Elodea nuttallii, J. Haz. Mat., 263(2013) 575-583

[8] Regier, N., L. Baerlocher, M. Munsterkotter, L. Farinelli, and C. Cosio, Analysis of the Elodea nuttallii transcriptome in response to mercury and cadmium pollution: development of sensitive tools for rapid ecotoxicological testing, Environ. Sci. Technol., 47(2013) 8825-8834.

[9] Bergman, B.G. and J.K. Bump, Mercury in aquatic forage of large herbivores: impact of environmental conditions, assessment of health threats, and implications for transfer across ecosystem compartments, Sci. Total Environ., 480(2014) 66-76.

[10] Regier, N., F. Larras, A.G. Bravo, V.G. Ungereanu, and C. Cosio, Hg bioaccumulation in the macrophyte Elodea nuttallii in the field and in microcosm: $\mathrm{Hg}$ in shoots accumulated from the water might involve $\mathrm{Cu}$ transporters, Chemosphere, 90(2013) 595-602.

[11] Zhang, P., J. Sun, J. Chen, J. Wei, W. Zhao, Q. Liu, and H. Sun, Effect of feeding selectivity on the transfer of methylmercury through experimental marine food chains, Mar. Environ. Res., 89(2013) 39-44.

[12] Cosio, C., E. Martinoia, and C. Keller, Hyperaccumulation of cadmium and zinc in Thlaspi caerulescens and Arabidopsis halleri at the leaf cellular level, Plant Physiol., 134(2004) 716-725.

[13] Cosio, C., L. DeSantis, B. Frey, S. Diallo, and C. Keller, Distribution of cadmium in leaves of Thlaspi caerulescens, J. Exp. Bot., 56(2005) 765-775.

[14] Castro, R., S. Pereira, A. Lima, S. Corticeiro, M. Valega, E. Pereira, A. Duarte, and E. Figueira, Accumulation, distribution and cellular partitioning of mercury in several halophytes of a contaminated salt marsh, Chemosphere, 76(2009) 1348-1355.

[15] Lawson, N.M. and R.P. Mason, Accumulation of mercury in estuarine food chains, Biogeochemistry, 40(1998) 235-247.

[16] Mason, R.P., J.R. Reinfelder, and F.M.M. Morel, Uptake, toxicity, and trophic transfer of mercury in a coastal diatom, Environ. Sci. Technol., 30(1996) 1835-1845.

[17] Regier, N., B. Frey, B. Converse, E. Roden, A. Grosse-Honebrick, A.G. Bravo, and C. Cosio, Elodea nuttallii roots effect on bacterial communities and $\mathrm{MMHg}$ proportion in a $\mathrm{Hg}$ polluted sediment, Plos One, 7(2012) e45565. 
[18] Coulaud, R., O. Geffard, B. Xuereb, E. Lacaze, H. Queau, J. Garric, S. Charles, and A. Chaumot, In situ feeding assay with Gammarus fossarum (Crustacea): Modelling the influence of confounding factors to improve water quality biomonitoring, Water Res., 45(2011) 6417-29.

[19] Besse, J.P., M. Coquery, C. Lopes, A. Chaumot, H. Budzinski, P. Labadie, and O. Geffard, Caged Gammarus fossarum (Crustacea) as a robust tool for the characterization of bioavailable contamination levels in continental waters: towards the determination of threshold values, Water Res., 47(2013) 650-60.

[20] USEPA, Method 1631: Mercury in water by oxidation, purge and trap, and CVAFS, US Environmental Protection Agency, Office of Water, Revision E, (2002).

[21] USEPA, Method 1630: Methyl mercury in water by distillation, aqueous ethlylation, purge and trap, and CVAFS, US Environmental Protection Agency, Office of Water, draft, (2001).

[22] Hammerschmidt, C.R. and W.F. Fitzgerald, Methylmercury in mosquitoes related to atmospheric mercury deposition and contamination, Environ. Sci. Technol., 39(2005) 3034-9.

[23] Gimbert, F., A. Geffard, S. Guedron, J. Dominik, and B.J.D. Ferrari, Mercury tissue residue approach in Chironomus riparius: Involvement of toxicokinetics and comparison of subcellular fractionation methods, Aqu. Toxicol., 171(2016) 1-8.

[24] Bates, D.M. and J.M. Chambers, Nonlinear models, in Statistical Models J.M. Chambers and T.J. Hastie, Editors. 1992, Chapman \& Hall: London. p. 421-454.

[25] R Development Core Team, V., Austria, R: a language and environment for statistical computing. R Foundation for Statistical Computing, (2013).

[26] Bravo, A.G., S. Le Faucheur, M. Monperrus, D. Amouroux, and V.I. Slaveykova, Species-specific isotope tracers to study the accumulation and biotransformation of mixtures of inorganic and methyl mercury by the microalga Chlamydomonas reinhardtii, Environ. Pollut., 192(2014) 212-5.

[27] Pickhardt, P.C., C.L. Folt, C.Y. Chen, B. Klaue, and J.D. Blum, Impacts of zooplankton composition and algal enrichment on the accumulation of mercury in an experimental freshwater food web, Sci. Total Environ., 339(2005) 89-101.

[28] Chetelat, J., L. Cloutier, and M. Amyot, An investigation of enhanced mercury bioaccumulation in fish from offshore feeding, Ecotoxicology, 22(2013) 1020-32.

[29] Hodson, P.V., K. Norris, M. Berquist, L.M. Campbell, and J.J. Ridal, Mercury concentrations in amphipods and fish of the Saint Lawrence River (Canada) are 
unrelated to concentrations of legacy mercury in sediments, Sci. Total Environ., 495(2014) 218-28.

[30] Pickhardt, P.C., M. Stepanova, and N.S. Fisher, Contrasting uptake routes and tissue distributions of inorganic and methylmercury in mosquitofish (Gambusia affinis) and redear sunfish (Lepomis microlophus), Environ. Toxicol. Chem., 25(2006) 2132-42.

[31] Wang, W.-X., I. Stupakoff, C. Gagnon, and N.S. Fisher, Bioavailability of inorganic and methylmercury to a marine deposit-feeding polychaete, Environ. Sci. Technol., 32(1998) 2564-2571.

[32] Zhong, H. and W.-X. Wang, Metal solid interactions controlling the bioavailability of mercury from sediments to clams and sipunculans, Environ. Sci. .Technol., 40(2006) 3794-3799.

[33] Dang, F. and W.X. Wang, Subcellular controls of mercury trophic transfer to a marine fish, Aqu. Toxicol., 99(2010) 500-506.

[34] Carrasco-Gil, S., A. Alvarez-Fernandez, J. Sobrino-Plata, R. Millan, R.O. CarpenaRuiz, D.L. Leduc, J.C. Andrews, J. Abadia, and L.E. Hernandez, Complexation of $\mathrm{Hg}$ with phytochelatins is important for plant Hg tolerance, Plant Cell Environ., 34(2011) 778-791.

[35] Park, J., W.Y. Song, D. Ko, Y. Eom, T.H. Hansen, M. Schiller, T.G. Lee, E. Martinoia, and Y. Lee, The phytochelatin transporters AtABCC1 and AtABCC2 mediate tolerance to cadmium and mercury, Plant J., 69(2012) 278-288.

[36] Gupta, M., R.D. Tripathi, U.N. Rai, and P. Chandra, Role of glutathione and phytochelatin in Hydrilla verticillata (lf) Royle and Vallisneria spiralis L. under mercury stress, Chemosphere, 37(1998) 785-800.

[37] Tai, H.C. and C. Lim, Computational studies of the coordination stereochemistry, bonding, and metal selectivity of mercury, J. Physic. Chem. A, 110(2006) 452-462.

[38] Geffard, A., H. Sartelet, J. Garric, S. Biagianti-Risbourg, L. Delahaut, and O. Geffard, Subcellular compartmentalization of cadmium, nickel, and lead in Gammarus fossarum: Comparison of methods, Chemosphere, 78(2010) 822-829.

[39] Taylor, V.F., D. Bugge, B.P. Jackson, and C.Y. Chen, Pathways of $\mathrm{CH}_{3} \mathrm{Hg}$ and $\mathrm{Hg}$ ingestion in benthic organisms: an enriched isotope approach, Environ. Sci. Technol., 48(2014) 5058-5065. 


\section{Figure legends}

Figure 1: $\mathrm{Hg}$ concentration $\left(\mu \mathrm{g} \cdot \mathrm{g}^{-1}\right)$ in $\mathrm{G}$. fossarum as a function of $\mathrm{Hg}$ concentrations $\left(\mu \mathrm{g} \cdot \mathrm{g}^{-}\right.$ ${ }^{1}$ ) in plants at the beginning of gammarids exposure. (A) THg concentration in G. fossarum fed 7 day-long with the $\mathrm{IHg}$ or MMHg contaminated intracellular or cell wall compartment of E. nuttallii as a function of $\mathrm{THg}$ concentrations. (B) $\mathrm{IHg}$ or $\mathrm{MMHg}$ concentration in $G$. fossarum fed 7 day-long with the MMHg-contaminated intracellular or cell wall compartment of E. nuttallii as a function of respectively the $\mathrm{IHg}$ and $\mathrm{MMHg}$ concentrations in plants. Slopes and $\mathrm{R}^{2}$ of the respective linear regressions are indicated. Values with different letters are significantly different $(p<0.05 ; \mathrm{n}=3)$.

Figure 2: $\mathrm{THg}, \mathrm{MMHg}$ and $\mathrm{IHg}$ accumulation in G. fossarum fed with the IHg contaminated intracellular (A) or cell wall (B) compartment. The vertical line represents the beginning of the depuration phase.

Figure 3: $\mathrm{THg}, \mathrm{MMHg}$ and $\mathrm{IHg}$ uptake in G. fossarum fed with the MMHg contaminated intracellular (A) or cell wall (B) compartment. The vertical line shows the beginning of the depuration phase. 


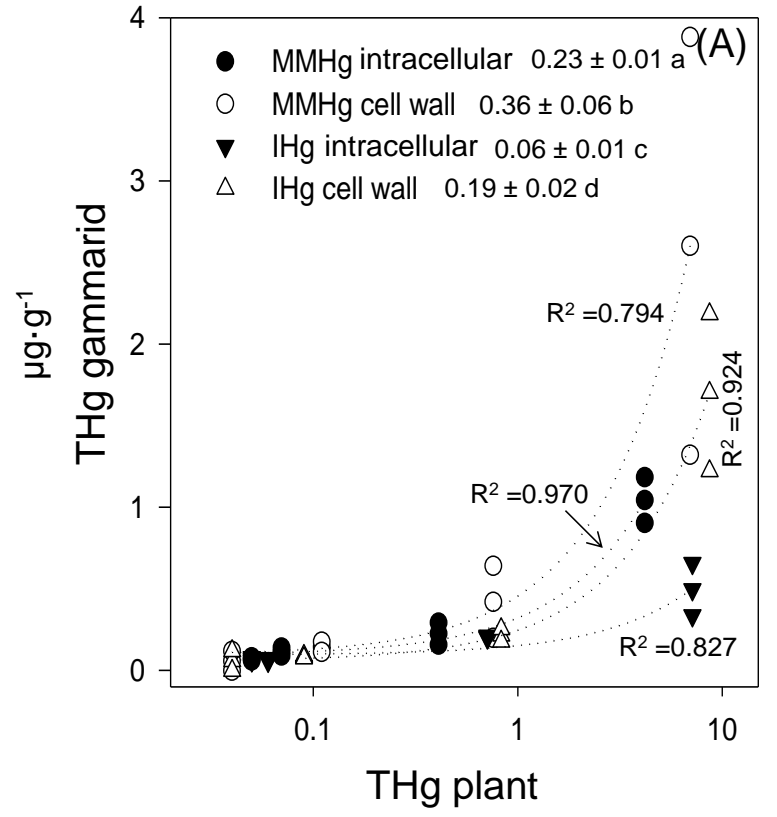

Figure 1

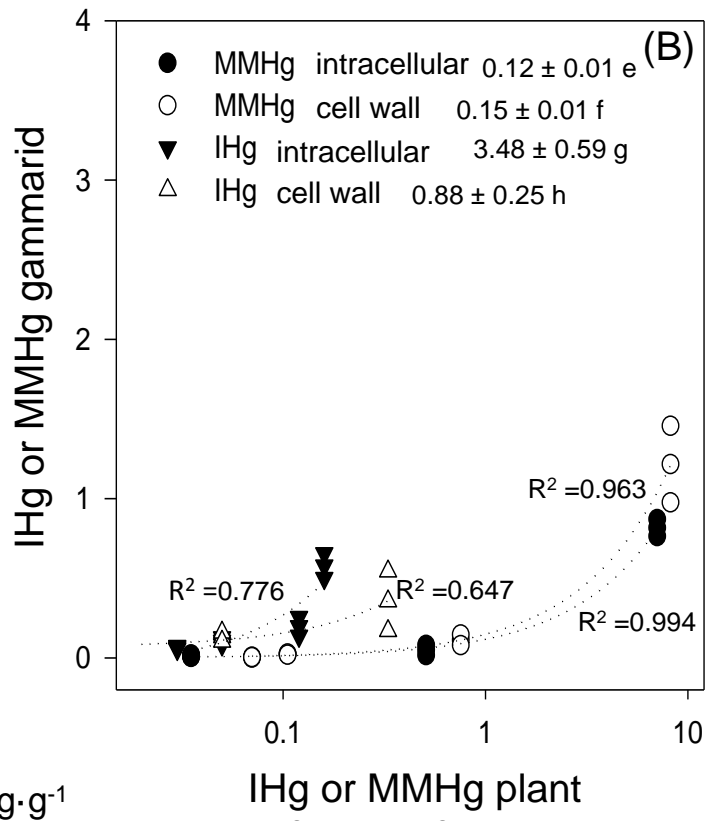

$\mu g \cdot g^{-1}$
$\mathrm{IHg}$ or $\mathrm{MMHg}$ plant 

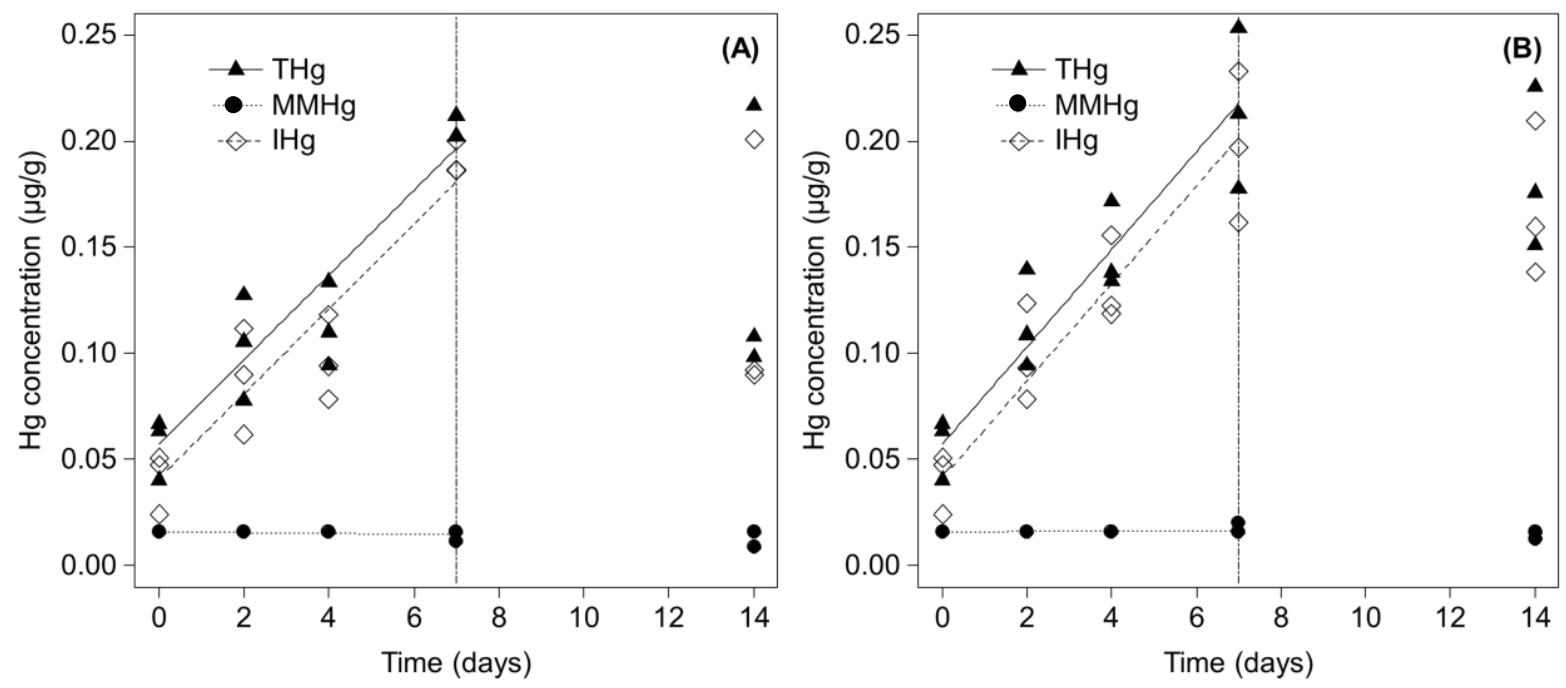

Figure 2 

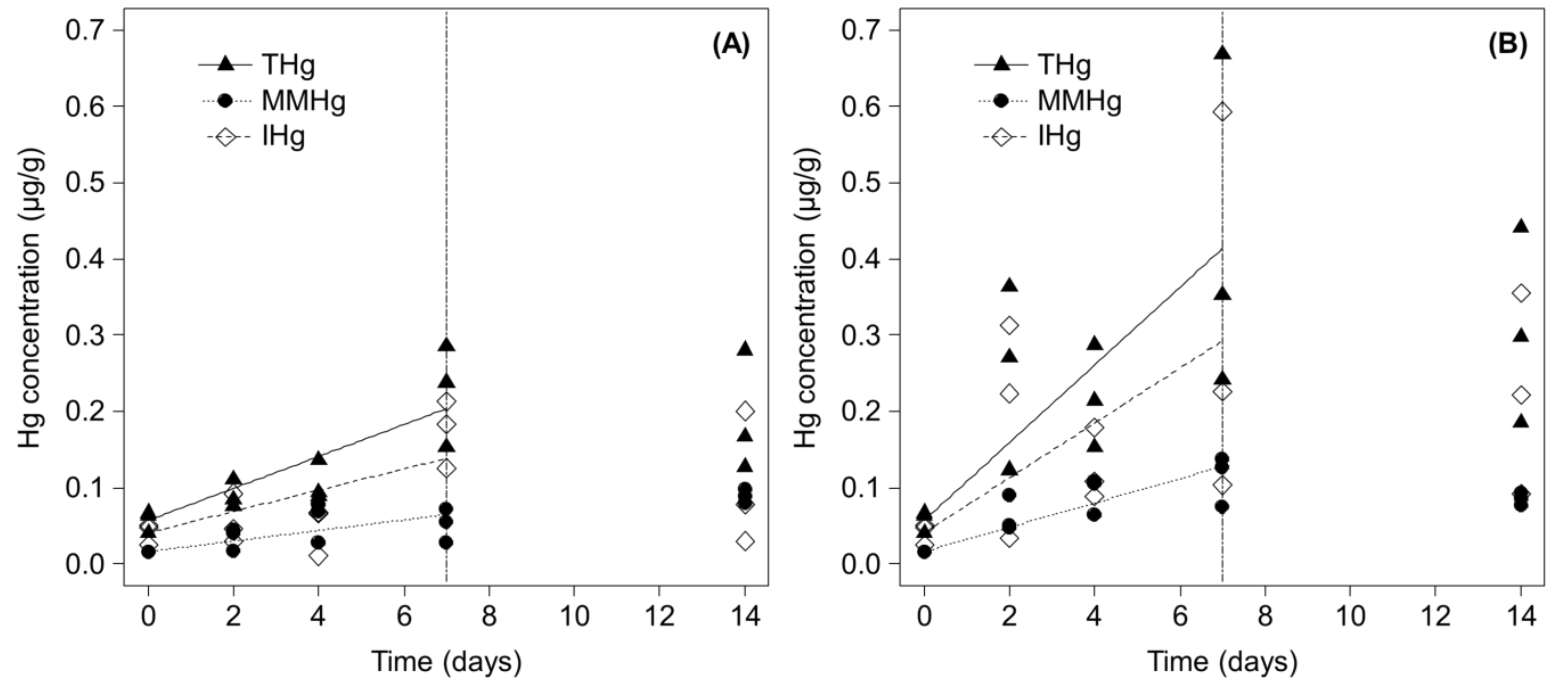

Figure 3 
Table 1: THg and MMHg concentrations measured (mean $\pm \mathrm{SD}$ ) in shoots of E. nuttallii $\left(\mu \mathrm{g} \cdot \mathrm{g}^{-1}\right)$ at the beginning of exposure of G. fossarum. Values that share similar letters are not significantly different (ANOVA with the post-hoc Tukey's HSD test, $p<0.05 ; \mathrm{n}=3$ ).

\begin{tabular}{llllll}
\hline & \multicolumn{2}{l}{ THg } & & \multicolumn{1}{l}{ MMHg } \\
\cline { 2 - 3 } Exposure treatment & Intracellular & Cell wall & & Intracellular & Cell wall \\
\hline Control & $0.05 \pm 0.01 \mathrm{a}$ & $0.04 \pm 0.001 \mathrm{a}$ & & $0.04 \pm 0.02 \mathrm{a}$ & $0.07 \pm 0.02 \mathrm{a}$ \\
$\mathbf{0 . 2} \boldsymbol{\mu g} \cdot \mathbf{L}^{-\mathbf{1}} \mathbf{M} \mathbf{M H g}$ & $0.07 \pm 0.004 \mathrm{a}$ & $0.11 \pm 0.004 \mathrm{a}$ & & $0.04 \pm 0.02 \mathrm{a}$ & $0.11 \pm 0.05 \mathrm{a}$ \\
$\mathbf{4} \boldsymbol{\mu g} \cdot \mathbf{L}^{-\mathbf{1}} \mathbf{M} \mathbf{M H g}$ & $0.41 \pm 0.02 \mathrm{~b}$ & $0.76 \pm 0.07 \mathrm{~b}$ & & $0.51 \pm 0.21 \mathrm{~b}$ & $0.76 \pm 0.11 \mathrm{~b}$ \\
$\mathbf{2 0} \boldsymbol{\mu g} \cdot \mathbf{L}^{-\mathbf{1}} \mathbf{M M H g}$ & $4.18 \pm 0.48 \mathrm{e}$ & $6.98 \pm 0.52 \mathrm{c}$ & & $7.06 \pm 1.32 \mathrm{c}$ & $8.22 \pm 4.60 \mathrm{c}$ \\
$\mathbf{0 . 2} \boldsymbol{\mu g} \cdot \mathbf{L}^{-\mathbf{1}} \mathbf{I H g}$ & $0.06 \pm 0.01 \mathrm{a}$ & $0.09 \pm 0.01 \mathrm{a}$ & & $0.05 \pm 0.04 \mathrm{a}$ & $0.04 \pm 0.02 \mathrm{a}$ \\
$\mathbf{4} \boldsymbol{\mu g} \cdot \mathbf{L}^{-\mathbf{1}} \mathbf{I H g}$ & $0.71 \pm 0.17 \mathrm{~b}$ & $0.83 \pm 0.07 \mathrm{~b}$ & & $0.05 \pm 0.09 \mathrm{a}$ & $0.09 \pm 0.04 \mathrm{a}$ \\
$\mathbf{2 0} \boldsymbol{\mu g} \cdot \mathbf{L}^{\mathbf{- 1}} \mathbf{I H g}$ & $7.15 \pm 0.26 \mathrm{c}$ & $8.67 \pm 1.27 \mathrm{c}$ & & $0.07 \pm 0.02 \mathrm{a}$ & $0.04 \pm 0.02 \mathrm{a}$ \\
\hline
\end{tabular}


Table 2 Toxicokinetic parameters (uptake rate $a$, uptake rate constant $k_{u}$ ) of $\mathrm{THg}, \mathrm{IHg}$ and MMHg accumulation in G. fossarum fed with the MMHg or IHg contaminated intracellular or cell wall compartment of E. nuttallii. For each $\mathrm{Hg}$ form, values that share similar letters are not significantly different (glrt; ns = not significant; nd=not determinable).

\begin{tabular}{|c|c|c|c|c|}
\hline \multirow[t]{2}{*}{$\mathrm{Hg}$ species } & Exposure & $\begin{array}{c}a \pm \mathrm{SE} \\
\mu \mathrm{g} \cdot \mathrm{Hg} \cdot \mathrm{g}^{-1} \cdot \mathrm{d}^{-1}\end{array}$ & $\begin{array}{c}k_{u} \\
\mathrm{~g}_{\text {plant }} \cdot \mathrm{g}^{-1} \cdot \mathrm{d}^{-1}\end{array}$ & $\mathrm{R}^{2}$ \\
\hline & IHg & & & \\
\hline \multirow{2}{*}{$\mathrm{THg}$} & intracellular & $0.020 \pm 0.001^{\mathrm{a}}$ & 0.028 & 0.90 \\
\hline & cell wall & $0.023 \pm 0.002^{b}$ & 0.028 & 0.89 \\
\hline \multirow{2}{*}{$\mathrm{MMHg}$} & intracellular & $-0.0002 \pm 0.0001^{\mathrm{ns}}$ & nd & 0.79 \\
\hline & cell wall & $0.0001 \pm 0.0001^{\mathrm{ns}}$ & nd & 0.49 \\
\hline \multirow{3}{*}{$\mathrm{IHg}$} & intracellular & $0.020 \pm 0.001^{\mathrm{a}}$ & 0.030 & 0.90 \\
\hline & cell wall & $0.023 \pm 0.001^{\mathrm{b}}$ & 0.031 & 0.90 \\
\hline & MMHg & & & \\
\hline \multirow[t]{2}{*}{$\mathrm{THg}$} & intracellular & $0.021 \pm 0.003^{\mathrm{a}}$ & 0.051 & 0.80 \\
\hline & cell wall & $0.051 \pm 0.009^{\mathrm{b}}$ & 0.067 & 0.56 \\
\hline \multirow[t]{2}{*}{$\mathrm{MMHg}$} & intracellular & $0.007 \pm 0.001^{\mathrm{c}}$ & 0.014 & 0.66 \\
\hline & cell wall & $0.016 \pm 0.002^{\mathrm{d}}$ & 0.021 & 0.70 \\
\hline \multirow[t]{2}{*}{$\mathrm{IHg}$} & intracellular & $0.014 \pm 0.003^{c}$ & nd & 0.67 \\
\hline & cell wall & $0.036 \pm 0.009^{\mathrm{d}}$ & nd & 0.38 \\
\hline
\end{tabular}

